\title{
Özbek Türklerine Ait Destanlarda Kadın İmgeleri Üzerine Değerlendirmeler
}

\section{Dr. Tuğba Teke ${ }^{1^{*}}$}

Gelis tarihi: 15.04 .2020

Kabul tarihi: 07.05.2020

\section{Atıf bilgisi:}

IBAD Sosyal Bilimler Dergisi

Sayı: $8 \quad$ Sayfa: $160-177$

Yıl: 2020 Dönem: Güz

This article was checked by Turnitin.

Similarity Index 19\%

Bu makalede araștırma ve yayın etiğine uyulmuştur.

1 Zonguldak Bülent Ecevit Üniversitesi, Türkiye, tugbateke@beun.edu.tr ORCID ID 0000-0002-2296-7250

\section{* Sorumlu yazar}

ÖZ

Destanlar, her milletin kendi geçmişini bulduğu ilk epik verimleridir. Geçmiş ve gelecek kuşak arasında bilgi aktarımından oluşan köprü görevini üstlenen destanlarda sosyal, siyasi, dinî ve ekonomik hayata dair bilgilerin olması da elbette muhakkaktır. Toplumların medeniyet tarihindeki yerini belirlemede kadının yerinin ne olduğu konusu ise belirleyici ve önemli bir ölçüttür. Bu bağlamda çalışmada sözlü kültürün zengin ve önemli metinlerinden olan Özbekistan sahası destanları çerçevesinde kadına biçilen farklı roller ve destani dönemde kadınlara bakış irdelenmiştir. Söz konusu destanlarda kadın kahramanların toplumsal rolleri, karakter ve fiziksel özellikleri irdelenmiş; diğer Türk boylarının destanlarındaki kadın kahramanlar ile ortak ve farklı yönlerini tespit etmek amaçlanmıştır. Çalışmada halkbilimi araştırma metotları içerisinde yer alan ve antropologlar tarafindan geliştirilen işlevsel yöntem esas alınmıştır.

Anahtar Kelimeler: Destan, Özbekistan, Kadın. 


\section{Considerations on the Women's Image in the Epics of Uzbek Turks}

\section{Dr. Tuğba Teke ${ }^{1^{*}}$}

First received: 15.04 .2020

Accepted: 07.05.2020

\section{Citation:}

IBAD Journal of Social Sciences

Issue: 8

Pages: 160-177

Year: 2020

Session: Fall

This article was checked by Turnitin. Similarity Index 19\%

\footnotetext{
* Zonguldak Bülent Ecevit Universitiy, Turkey, tugbateke@beun.edu.tr

ORCID ID 0000-0002-2296-7250
}

\section{${ }^{*}$ Corresponding Autho}

\begin{abstract}
Epics are the first epic productions in which every nation finds its own past. Of course, there is information about social, political, religious and economic life in epics that act as a bridge between the past and future generations. What is the place of women in determining the place of societies in the history of civilization is a determining and important criterion. In this context, the different roles given to women within the framework of the Uzbekistan field epics, one of the rich and important texts of the oral culture, and the view of women in the epic period were examined. Social roles, characters and physical characteristics of female heroes were examined in these epics; It is aimed to identify the common and different aspects of female heroes in the epics of other Turkish tribes. In this study has been based on the functional method which is included in folklore research methods and has been improved by anthropologists.
\end{abstract}

Keywords: Epic, Uzbekistan, woman. 


\section{GİRIŞ}

Çalışma konusu Özbek destan geleneği içerisinde kadın imgeleri olmakla birlikte, konuyla ilgili olduğu için destan kavramı üzerinde kısaca durmak gerekmektedir. Dilimize Farsçadan giren ve Aristo'dan günümüze kadar pek çok tanımı yapılan destan kelimesi, anlatmaya dayalı bir halk edebiyatı türünü ifade eder. Kelimenin çok geniş bir kullanım alanı vardır. Destanlar, kahramanların olağanüstü eylemlerini coşkulu bir dille anlatan, bir milletin heyecanlarını hareketlendiren, duygu ve düşünce yapısını oluşturan, milletlerin millet olma yolundaki çabalarından izler taşıyan ve içinde efsanevi, mitolojik ve tarihî unsurlar barındıran anlatı türüdür.

Destan sözcügü Türkçe Sözlük'te (TDK, 2005) “Tarih öncesi tanrı, tanrıça, yarı tanrı ve kahramanlarla ilgili olağanüstü olayları konu alan şiir, epope"; "Bir kahramanlık hikâyesini veya bir olayı anlatan, koşma biçiminde, ölçüsü on bir hece olan halk şiiri" ve "Çağdaş Türk edebiyatında biçim ve içerik yönünden, geleneksel destanlardan ayrılık gösteren uzun kahramanlık şiiri” olmak üzere üç farklı biçimde tanımlanmıştır. Kamus-ı Türkî̀ de (Sami, 1989, s. 598) ise "Hikâye, masal, sergüzeşt, bir vaka hal hikâye eden amiyane manzume; Osmanlıca-Türkçe Ansiklopedik Lugat'te (Devellioğlu, 1970, s. 178) "hikâye, kıssa" terimleri ile karşıllanmaktadır. Dictoinnaire Larousse'ta (Milliyet, 1994, s. 646) ise "gerçek ile gerçeküstünün, efsane ile tarihin birbirine karıştı̆̆ bir kahramanı, kahramanlık olaylarını veya önemli tarihsel bir olayı övüp yücelten uzun manzume" tanımı verilmektedir. Aristo'ya göre destan, temsilî ve anlatmaya dayalıdır, ölçülüdür ve belli bir uzunluktadır; trajedi gibi destan da kahramanlık olaylarının ölçülü bir şeklide sunulmasıdır.

Edebî bir tür olarak destan kavramına ise farklı araştırmacılar tarafından farklı ve geniş tanımlamalar yapılmıştır. Nitekim İslam Ansiklopedisi'nde Kâzım Yetiş destanı "Âşsk edebiyatı ve musikisinde bir nazım şeklinin de adı olan destan kelimesinin ası Farsça dastandır. Batı dillerinde bunun karşılığı olarak Grekçede şairlerin saz eşliğinde söyledikleri şiirlere verilen epos adından türetilen epopee (epopoeia) kullanılır. Destan "hikâye, masal, sergüzeșt, manzum hikâye (kıssa), vak'a, tarih, roman ve hayvan masalı (fabl)" gibi anlamlara da gelmektedir" (Yetiş, 1994, s. 202) şeklinde tanımlanmaktadır.

Ali Canip Yöntem, destanlar için "Bir epopenin mevzuunu, o mevzudaki kahramanları hatta kahramanların maceralarını milletlerin maşeri muhayyileleri yaratmıştır. Yani bütün bunlar halkın malıdır... Epopelerde mabutlarla kahramanlar bir cihan içinde yaşarlar... Epope medeni insanın malıdır... Epopelerde her şey fevkaladenin fevkindedir" (Yöntem, 1930, s. 1-5) ifadelerini kullanmıştır.

Şükrü Elçin, Halk Edebiyatına Giriş (2005, s.72) adlı eserinde destan için şu bilgileri kaydetmiştir: "Destan (epos), bir boy, ulus (kavim) veya millet hayatında tam estetik hüviyet kazanmamış eser sayılan efsanelerden sonra nazım şeklinde ortaya çıkan en eski halk edebiyatı mahsullerinden biridir. Sözlü geleneğe bağlı olan bu anonim mahsuller, zaman ve mekân içinde cemiyetin iradesini ellerinde tutan "kahraman-bilge" şahsiyetlerin menkabevî ve hakikî hayatları etrafinda teşekkül etmiş uzun, didaktik hikâyelerdir."

Köroğlu Destanı'nda Kahraman ve Atının Doğumu ile İlgili Motiflerin Tahlili adlı çalışmasında destanların milletlerin hayal ve hafizasındaki efsanevî tarihler olduğunu belirten İsa Özkan bugün en zengin destan külliyatına sahip milletlerin başında geldiğimizi belirtmektedir. (Özkan, 1997, s. 223)

Halk edebiyatı araştırmalarının önde gelen isimlerinden Öcal Oğuz, destan terimi için "Farklı anlamlarda halk hayatında ve terim olarak değişik edebiyat geleneklerinde geçmişten günümüze yaygın olarak kullanılmıştır. Halk edebiyatı içinde de hem anonim ürünler olan olağanüstü kahramanlık anlatıları hem de bu anlatılandan sonra ortaya çıkan "halk hikâyeleri" karşılığında kullanıldığı gibi, âşık şiirinde heceyle söylenen bir şiir türünün adı olarak da karşımıza çıkmaktadır” (Oğuz, 2004, s. 5) demektedir.

Özbek Türkleri de diğer Türk boyları gibi pek çok epik eser yaratmış ve onları hafızasında dikkatlice saklamıştır. Alpamış, Rüstem Han, Ayçınar, Köroğlu, Küntogmuş gibi onlarca halk destanı nesilden nesile söylenegelen değerli epik eserlerdir. Manevi, tarihî ve kültürel önemi büyük olan bu Özbek halk destanlarını kaydetme ve öğrenme meselelerinin ise Ekim Devrimi'nden sonra başladığı söylenebilir.

Selami Fedakâr, Özbeklerde destan anlayışı ve Özbek destanlarının tasnifi konusundaki yazısında özellikle Jirmunskiy, Zarifov, Saidov, Mirzayev, Sarımsakov gibi araştırmacıların görüşlerine yer 
vermiştir. Bu doğrultuda V.M. Jirmunskiy ve H.T. Zarifov Özbek Kahramanlık Destanı adlı çalışmada destan türünü; "Kahramanlık ideali etrafında oluşturulan, geçmiş hakkındaki hikâyeler ve rivayetler" olarak tarif etmiș; T. Mirzayev ile Bahadır Sarımsakov "Destan, halkın tarih içinde kendi kendini anlamasının büyük bir ifadesi olarak kadimî devirlerde arkaik folklor zemininde meydana gelmiş olup; tarihi gerçekliği, fantezi temelinde yaratılmış ideal tiplerde tasvir eden, melodi ve icra ile sıkı sıkıya bağlı olan, hacimli ve geniş çaplı bir eserdir. Epik ve etkileyici olma destana has bir özelliktir. Destan, konu ve kompozisyon bakımından kapsamlı olayları içine alır. Bu olaylar içerik olarak kahramanlık karakterine sahiptir ve bunların aktarımı halkın idealindeki bir tek kahramanın etrafında birleștirilir. Halkın bütün imkânları ve arzuları, olağanüstü güçlere sahip olan bu kahramanda vücut bulur. Bu özellikler, destanların özel üslubunu, şekil ve türünü meydana getirmiş̧ir.” biçiminde; M. Saidov ise, "destan çok mürekkep bir sanat eseri olup, bir yaratmanın destan olabilmesi için edebî bir metninin, müziğinin ve ayrıca ezberleme yeteneği güçlü ve saz çalmasını çok iyi bilen bir anlatıcının olması şarttır" şeklinde tanımlamışlardır. (Fedakâr, 2009, s. 17)

M. Saidov, ayrıca Melike Ayyar Destanı'nın üslup özelliklerinden bahsettiği çalışmasında epik bir eserin destan olabilmesi için öncelikle sanatsal bir metnin ve bu metne uygun bir müziğin olması gerektiğinden söz eder (Saidov, 1960, s. 33-36).

Said Alimoğlu Özbek Folklorunun Tür Hususiyetleri başlıklı çalışmasında Özbek folklorunu ifade edilme usulü, icra edilme hususiyeti ve bediî şekilleri esas alarak dört başlık altında incelemiştir. Destanın da içinde olduğu efsane, rivayet, nakil, masal, sözlü kıssa, hikâye tarihi türkü ve biyografik türküleri epik türdeki folklor örnekleri dairesine almıştır (Alimoğlu, 1997, s. 57).

Bir toplumun kaderini tayin eden olayları konu eden destanlar, çeşitli normlar ve epik gelenekler etrafinda gelişerek ait olduğu toplumun geçmişini, değişerek ve zamanla gelişerek tasvir eder. Millî birlik ve beraberliğin yaşatılmasında önemli roller üstlenir. En eski Türk boylarından birisi olan ve Türkistan'ın merkezinde yaşayan Özbek Türkleri, zengin bir halk edebiyatı geleneğine sahiptir. Söz konusu gelenek içinde destanlar ayrı bir yere sahiptir.

Diğer Türk boylarının destanlarında olduğu gibi Özbek sahası destanlarında da kadınlar önemli bir yer tutmaktadır. İncelenen destanlar, Özbek Türklerinin tarih sahnesine çıktıkları dönemden itibaren kadına bakıs tarzını, millet olarak bir araya gelmelerinde ve sosyal hayatta kadının yerini ve kadın-erkek ilişkilerini ortaya koymaktadır. Şimdiye kadar üstünde bu yönüyle pek durulmayan Özbek Türklerinin destanlarında kadına dair önemli mesajlar, pek çok sosyal realite yer almaktadır. Destanlarda yüksek estetik tipler olarak aksettirilen kadınlar, genel anlamda kadınların insanlık tarihindeki özel anlamda ise Özbek tarihindeki önemli rolünü, akıl, anlayış ve ruhunu izah etmektedir.

Bu noktada kadın algısı ve kadının konumu hakkında fikir sahibi olabilmek için öncelikle kadın sözcüğünün anlamından hareket etmek daha doğru bir yaklaşım olacaktır. Sözcükler belli bir varlığı, olay ya da olguyu belirtmekle görevli dil birimleridir. Ayrıca insanın bir kavramla ilgili bilgi ve fikir edinebileceği en önemli kaynaktır. Kadın sözcüğünün köken itibarıyla 'hatun/katun'dan geldiği ve bir cinsi tanımlamada kullanıldığı bilinmektedir. Köktürk harfleriyle yazılmış Yenisey Yazıtları'nda ebçi, kişi, katın, kelin ve ög sözcükleri kadını ifade etmek üzere kullanılmıştır. Yine Çinceden alınmış kunçuy sözcüğü en sık geçenlerden biridir. Ebçi sözcügünün ise 'evde/çadırda oturan, ev işi yapan' manasında kullanıldığı görülmektedir. Dolayısıyla bu durum eski Türklerde kadına ev işleri ile meşgul olan, evde oturan bir imaj çizmiştir. Katın ve kelin sözcükleri ise akrabalık ilişkileri ile ilgili olup yeni bir eve/aileye mensup olma anlamı taşımaktadır.

İnsanlar arasında iletişimi sağlayan canlı bir varlık olan dil, kültür değerlerini dünden bugüne aktaran taşıyıcı bir fonksiyona sahiptir. Toplumların kültür unsurları dile aktarıldığından dolayı, dil, kültürün ve içtimai hayatın aynası gibidir. Dilin sosyal bir kurum olması, dil ile içtimai yapıyı oluşturan millet arasındaki ilişki göz önüne alınırsa Türkçede kadınla ilgili kelimeler, Türk kültür ve medeniyetinde kadının konumu hakkında yeterince bilgi vermektedir. Türkçenin söz varlı̆̆ına bakıldığında kadın kavramının çok zengin bir biçimde karş1landığı görülür. Bu söz varlı̆gı içinde kadın sosyal, hukuki, ailevi, akrabalık bağları ve benzer yönleri ile karşılanmıştır. Bunlar genel söz varlığı araştırmaları için önemli olduğu kadar, eski Türk toplumunun cinsiyet kültürünü ve kadının toplumdaki statüsünü göstermesi bakımından da son derece kıymetlidir. 
Özbek destanlarında kadın unsurunu, işlevsel kuramın temsilcilerinden hatta kurucularından olan Bronislaw Malinowski'nin kültür kavramına bakış açısı 1şı̆̆ında incelemeyi amaçladık. Malinowski, Bilimsel Bir Kültür Teorisi adlı eserinde kültüre farklı bir bakış açısı getirerek, onu insanın yeme, üreme, barınma, güvenlik gibi temel ihtiyaçlarının karşılanmasında bir araç olarak tanımlamıştır. Malinowski'ye göre kurumun doğası, işleviyle belirlenir. Malinowski bütün kültürlerin çözmek zorunda olduğu üç temel gereksinim düzeyini şöyle sıralamıştır: 1. Bir kültür, yiyecek ve üreme gereksinimleri gibi biyolojik gereksinimleri karşılamalıdır. 2. Bir kültür, hukuk ve eğitim gereksinimi gibi araçsal gereksinimleri karşılamalıdır. 3. Bir kültür, din ve sanat gibi bütünleyici gereksinimleri karşılamalıdır. (Malinowski, 2000, s. 22) Eğer antropologlar bir kültürün bu gereksinimlerini karşılama yollarını çözümleyebilirlerse Malinowski’ye göre kültürel özelliklerin kökenine de ulaşabilirler. Bu görüşlerden hareketle, toplumun üyeleri tarafından paylaşılan, aktarılan görüşler ve değer yargıları olarak tanımlanabilen kültürün ögeleri her toplumda ortak nitelikler taşımaz. Söz gelimi her kültürde kadın ve erkeğe biçilen roller ve toplumların kadın algısı farklıdır.

Joseph Campbell, mit ve masalların gizemini çözmek üzere kaleme aldığı Kahramanın Sonsuz Yolculuğu adlı eserinde psikanalistlerin cesur ve çığır açıcı yazılarının mitoloji öğrencileri için vazgeçilmez olduğunu, Freud, Jung ve ardından gelenlerin, mitin mantığının, kahramanlarının ve yararlarının modern zamanlara dek canlı kalmalarını sağladıklarını ifade etmiştir. (Campbell, 2018, s. 14) Bu sebeple, incelemeye aldığımız destan metinlerindeki mitolojiye özgü durumların temelinde de psikanalistlerin bu isabetli tespitlerinin varlığı görülmektedir.

Yüzlerce destan külliyatından oluşan Türk destancılık geleneğinin metinleri düşünüldügünde, bu metinlerde yer alan tek bir kadın kahramanın bile incelenmeye çalışılması zaman sınırlarının aşması demektir. Dahası, Özbek Türklerinin sözel hazinelerinden birini oluşturan destanlar konusunu araştırmaya başlayınca çok zengin, uçsuz bucaksız bir dünyanın içinde olduğumuzu fark ettik. Dolayısıyla, bu çalışmada bütün destanları değerlendirmek mümkün olmamıştır; ancak, ulaştığımız metinler, Özbek destancılık geleneğinde kadın kahramanların işlevlerini belirlemeye yetecek düzeydedir. $\mathrm{Bu}$ bağlamda Türk Dil Kurumu Yayınları aracılığıla basılan "Özbek Destanları" adlı destanlar dizisinden yararlanılmıştır: Erali ve Şirali Destanı, Melike Ayyar Destanı, Ayçınar Destanı, Huşkeldi Destanı, Belagerdan Destanı, Rüstem Han Destanı ve Dalli Destanı. Ayrıca Polken Şaire'e ait olan ve Münevver Tekcan, Ümit Özgür Demirci ve Gaybullah Babayarov tarafından Türkiye Türkçesine aktarılmış "Şeybani Han Destanı" ile "Özbek Türklerinin 'Şeker bilen Şirin' Destanı", "Özbek Kahramanlık Destanı Zülfizar", "Özbekçe Küntugmiş Destanı" ve "Göroglinin Tugiliși Destanı- Özbek Varyantı" adlı yüksek lisans tezi olarak hazırlanan destan metinlerindeki kadın unsurlar da tespit edilmiştir.

\section{Toplumsal Rolleri Bakımından Destan Kadınları}

\subsection{Anne Olarak Kadın}

Türk topluluklarında gerek İslamiyet'ten önce gerekse İslamiyet'in kabulünden sonra annelik her dönemde kutsal bir kurum olarak kabul edilmiştir. Türk sosyal hayatında, siyasette, ev içi rollerde hep aktif bir yapı sergileyen kadın; Türk kültür hayatının vazgeçilmez bir parçası olmuştur. Dolayısıyla tarihin en eski dönemlerinden itibaren varlık göstermiş Türk toplumları ve kültürleri hakkında fikir sahibi olmamıza olanak sağlayan destanlarda anne motifinin işlenmemiş olması düşünülemez.

"Türklerde ana, daha önce gelir ve "ana-baba" denirdi. Dede Korkut'ta ana babaya, "ana-ata" dendiği gibi. Göktürk Yazıtları ile Uygur Türklerinde de ana, babadan önce söylenirdi. Çin' de ise baba öne alınır ve "baba, ana" denirdi. Eski Türklerde "anaç" sözü, hem "anacığım" hem de "anasına çekmiş soylu kız" demekti. Babanın hakkı sonsuz değildi: Nitekim Dede Korkut'ta Dirse Han, çocuğu olmadığı için ağlıyor ve karısına "Bu suç senden midir, benden midir?" diye dert yanıyordu. Karısına kötü bir söz söylemiyor ve suçu eşit olarak, karısı ile kendisi arasında paylaştırıyordu." (Gültepe, 2013, s. 261)

İncelediğimiz destanlarda annenin oğula, oğulun anneye karşı bağlılık duygusunun kuvvetli olduğu görülmektedir. Bu duygu genellikle üvey anneleri tarafindan iftiraya uğramış evlatların, padişah olan babaları tarafından darağacına asılmaları esnasında ortaya çıkar. Son anda oğullarının asılacağını ögrenen anne, ağlaya sızlaya ve perişan bir halde evlatlarının peşine düşer. Evlatlarının yerine 
kendisini asmalarını söyleyecek derecede fedakâr ve oğullarına karşı merhamet dolu olduğu görülür. Şeker Bilen Şirin Destanı'nda Botaköz Hanım oğullarının cellatlar tarafından sürüklenerek götürüldüğünü görür ve feryat figan edip ağlamaya başlar:

"Felek başıma zulüm saldl, diye

Olduğu yerde ăglayıp feryat etti.

Ne günah işledi iki oğlum diye,

Viran oldu oynayıp büyüdüğ̈̈m ilim diye,

Hazan oldu taze açmış gülüm diye,

Saçını yayarak ağlar sızlar gider,

Bir kabahat işledi iki oğlum diye,

Bu sözleri söyleyip slkıntıyla ağlar.

Cellatların gölgesini görür

Cellatlara koşup yetişir

Çıldırarak cellada soru sorar,

A ğlayıp kendini ateşe atar.” (Çolak, 2017, s. 296)

Destanlarda anne-oğul arasındaki ilişkilerin ilk örneklerini, Mezapotamya' nın ilk medeniyet merkezlerinden olan Sumer ülkesinde yaratılan, ölüm karşısında insanın çaresizliğini ve açmazını konu edinen Gılgamış Destanı'nda buluruz. Destanda Gılgamış, ölümlü insanlara benzemeyen, kükremesi azgın firtınayı, soluğu ateşi andıran Humbaba ile vuruşmaya karar verir. Ancak annesi kraliçe Ninsun'nun izni ve duası olmadan böyle bir işe girişmez. Ardından annesi kraliçe Ninsun'un huzuruna çıar ve şu sözleri söyler: "Ninsun, dineleyecek misin beni? Uzun yolculuğa çıkmam gerek. Humbaba' nın ülkesine varmak üzre bilinmeyen bir yolu geçip denenmemiş bir dögüşe, sedir ormanına ulaşıp Şamaş'ın tiksindiği kötülüğü ortadan kaldırıncaya değin, benim için dua et.” (Duralı, 2014, s. 31). Annesi Ninsun ise oğlunun bu uzun yolculuğunda Şamaş’tan yardım diler. Oğlu Gılgamış ve manevi oğlu kabul ettiği Enkidu' ya öğütler verir. İslamiyet' in kabulünden sonra teşekkül etmiş olan Battal Gazi Destanı'nda da aynı durumun varlığı dikkat çeker. Seyyit Battal Gazi, kâfir ordusuyla cenk etmeye giderken annesi Saide Hatun'dan himmet ve dua beklediğini destandaki şu sözlerle ifade eder: "Gece yarısı olunca Tevabil oradan ayrıldl. Cafer hemen atasının kara atını çıkardl, eyerledi. Kılıç kuşanıp gürzünü eğere bağladı. Rumîler gibi kıyafete büründü. Anası bu duruma çok ağladı.

- Bu vakitte nereye gidiyorsun? Gel gitme, vazgeç oğlum, dedi.

Cafer:

- Himmetini, duanı benden eksik etme, dedi ve atını mahmuzladı." (Köksal, 2014, s. 24)

Anne-oğul ilişkisinin olumsuz olduğu istisnai örnek Alpamış’tadır. Surhayil, hile ve kurnazlıkla kahramana zarar vermeye çalışan hain bir kadındır. Her biri ünlü birer alp olan yedi oğlu vardır. Bunlardan Karacan'ın Alpamış ile dost olması ve Müslümanlığı seçmesi annesinin düşmanlığını kazanmasina sebep olmuştur.

Özbek sahası destanlarında oğul sahibi anneler Dede Korkut Hikâyeleri'nin mukaddime kısmında ifade edildiği gibi iki gözün biri evlatlarını koruma içgüdüsü ve onların evden ayrılmaları korkusu ile oğullarını daima yanlarında ister. Bu durum ayrıca konar-göçer ve ataerkil bir toplumda evlat sahibi olmanın önemini gösterir. Erali ve Şirali Destanı'nda çocuklar mertliklerini ve cesaretlerini göstermek üzere sefere çıkmak isterler. Oğullarından ilk kez ayrılacağını öğrenen anneleri Gülmastura' nın söylediği sözler kadının oğullarına karşı duyduğu annelik hissini çok kuvvetli bir şekilde ifade etmektedir:

"Çocuklu ev daima olur lalezar,

İkinizi gördüm, oldum bikarar, 
Dal gibi boyunuza ananız kurban,

Ey kuzum-koçkarım nereye?

Göversin laleler mevsim gül olsun,

Karşı düşmanin daim sana el olsun,

Ben gibi kâben endamina kurban,

Bulgar'in töresi, canlar, nereye?" (Fedakâr, 2009, s. 101)

"İnsanın ve insanlığın tarihinde baskın anacıl bir dönem mutlaka vardır. Anacıl eylemlilik, annenin ve doğanın (dişil ilkenin) olumlu yaşanılan özelliklerini arama motifini yansıtır. Bu olumlu beklentiler, henüz kendi varoluş ve bütünlüğünün sorumluluk ve yükünü taşıma noktasına gelmemiş çocuğun annesinden beklentileridir. Bebek muhtaç olan, anne bebeğinin ihtiyacını şefkatiyle karşılayandır.”(Saydam, 2017, s. 76)

Özbek Türklerinin destanlarında anne fedakârdır; evladının ya da evlatlarının başı derde düştüğünde atak davranmak ister. Tıpkı Manas Destanı'nda Çıyırdı Hatun'un atlanıp silahlanarak oğlu Manas'ın yardımına koşması gibi. Benzer şekilde Dede Korkut Hikâyeleri'nde Kazan Han'ın eşi Boyu Uzun Burla Hatun'un oğlu Uruz'u ve onun peşinden giden kocası Kazan Bey’i kurtarmak için harekete geçmesi, Türk destanlarında kadının ana olarak önemli rolünü vurgulayan örneklerdir. Destanlarda anne rolünü üstlenmiş olan kadınlar evlatları uğruna fedakârlık göstermekten; şefkat ve merhametten kaçınmaz. Evladı için bazen kocası ile bile karşı karşıya gelen kadın önüne çıkan zorlukları yenmeye ve evladını güç durumlardan kurtarmaya çalışır. Bazen bu uğurda ölümü bile göze alır. Erali ve Şirali Destanı'nda Gülmastura oğullarının babaları Kara Han'ın emriyle asılmasına gönlü razı olmaz ve oğullarının yerine kendisini idam etmelerini ister.

“Tuttun mu sözünü yalancı gülünün,

Astırmak mı istiyorsun iki oğlunu,

Onların yerine beni astır, ey sultan,

Astırma o iki canımı, gönlümü.

Kan lazımsa astır onların yerine beni.”(Fedakâr, 2009, s. 193)

\subsection{Es Olarak Kadın}

"Türkçede bir erkek ile kadının aile kurma işlemine verilen isim yani evlenme deyimi de, evlenen erkek veya kızın baba ocağında ayrılarak ayrı bir ev (aile) meydana getirdiğini göstermektedir. Bunun mazisi de Gök-Türkçe kitabelerine kadar gitmektedir. Gök-Türkçe kitabelerden Suci yazıtında "İnim yiti, urım üç, kızım üç erti ebledim oglımın" (küçük kardeşim yedi, erkek evladım üç, kızım üç idi, oğlumu evlendirdim) cümlesinde 'eblemek' kelimesinin bugünkü Türkçe karşılığ 1 "evlenme” veya "evlendirme"dir $(\mathrm{eb}=\mathrm{ev})$." (Donuk, 1982, s. 164)

Özbek destanlarında kahramanlar ya evlenmek istedikleri sırada yiğitliklerini ispatlarlar ya da gelin adayı veya diğer rakiplerle dövüşürler. Devler, ejderhalar, periler gibi olağanüstü varlıklarla da savaşırlar. Destanlarda her şey zor elde edilir. Bu nedenle kolay bir şekilde evlilik görülmez. Savaş bittikten hemen sonra ya kızın babası ya da rakipler tarafından yeni bir savaş çıkar. Bu ikinci savaşta kahraman yaralanır. Bu defa gelin adayı savaş meydanında yiğitlik göstermek zorunda kalır.

Alpamış Destanı'nda Berçin, kendisiyle evlenmek isteyen kişiler için dört şart koşar. Bu dört şartı kim yerine getirirse ona varacağını söyler. Yerine getirilmesi gereken şartlar arasında ok atma, at yarıştırma ve güreş vardır:

"Babahan dağından yarış düzenliyorum

Gözünden yaşını damla damla akıtsa,

Çift kanatlı uçan atın kuyruğunu yüzdürse,

Babahan'da yarlşıp öne geçirsen,

Atı hizlı beyzadeye varırım. 
Yay çekişte yayı kırılmayana,

Ben varirim bu yayci pehlivana.

Bin adımlık yerden altın parayı vurana,

Ben varırım bu keskin nişanciya.

Savaş olursa hemen ileri çıkana,

Güreş yapıp doksan alpi yenene,

Ben varırım buğra bilekli pehlivana.

Şart koydum iyi-kötüye,

Ben varırım dört şartımı yapana." (Canpolat, Öz, 2000, s. 147)

Evlenecek erkeğe şartlar ileri sürmenin bir örneği de Küntoğmuş Destanı'nda yer alır. Fakat burada yer alan evlilikteki sınav motifi Alpamış gibi kahramanlık destanlarından farklıdır. Alpamış’ta Berçin, eş adaylarına kahramanlık destanlarının yapısına uygun biçimde ok atma, güreş tutma vb. şartlar sunarken; Helbeka, sözcülerine: "Her kim beni alayım diye gelirse satranç oyununu oynayıp yenmeden varmam" diyerek evleneceği kişiyi seçerken onun yiğitliğini değil zekâsını ölçmeye yarayan bir imtihana tabi tutar.

Özbek destanlarının çoğunda evlilik konusunda kadını küçümseyen kabuller yer almadığı gibi eş seçiminde iki cins eşit ölçüde söz hakkına sahiptir. Dalli Destanı'nda, Göroğlı Bey Erzurum ilinden kaçırarak getirdikleri Han Dalli'ye Avaz mı yoksa Hasan ile mi evlenmek istediğini sorar: "Dallican yavrum, ikisi de benim oğlum, ikisi de benim için bir. Seni, Avazhan' a diye buyursam da sana sormam iyi olur. Evladım ikisinden hangisine varırsın?"

Din olgusu da destanlarda evlilik ölçütü olabilmektedir. Şeybani Han Destanı'nda Şeybani Han'ın güzel ve kendisiyle aynı dinden olan bir Nogay kızı ile evlendirilmesi salık verilir: "Yalnızlıktan gönlün viran oldu mu/Gönlün isterse, güzel kızlar sevdireyim/Razı oldum senin sözüne/Hayranım senin kaşın gözüne/Yalnızlıktan kagılansan evladım/ Güzel kızlar alıvereyim özüne/ Gönlün isterse evlenmeyi oğlum/ Aynı dinden güzel kızlar bulunur.’(Tekcan vd. 2010, s. 85)

Destanlarda akraba evliliğinin iki örneği vardır. Bunlardan biri Ayçınar Destanı'dır. Ayçınar, babası ile akrabalarını bulmak üzere Endican'a doğru yola çıkar. Burada babası Halyar'ın Berdi ile Çariyar adlı ağabeyleri vardır. Onları Çariyar'ın oğlu Amanyar karşılar. Bir süre sonra Aman ile Ayçınar birbirlerine âşık olur ve evlenirler. İkinci örneği ise Alpamış' tır. Destanın merkezi kahramanı Alpamış amcasının kızı Berçinay ile evlenir.

\section{3. Çok Eşlilik ve Kuma}

Proto- Türklerin aile yapısının temelde monogami diye ifade edilen tek eşli bir evlilik modeline dayanmasına karşılık Özbek sahası Türk destanlarında erkek kahramanların bazı durumlarda birden çok kadınla evlendiğine (polijini) tesadüf edilir. Anlatılarda erkek kahramanın ilk eşinden çocuk sahibi olamaması, kadının erkeğe evlilik ısrarı, güç duruma düşmüş kadını korumak ve sahip çıkmak ya da tarafların birbirlerine âşık olması gibi sebepler çok eşliliğe zemin hazırlar.

Anadolu ve Rumeli'de Türklüğün ve Müslümanlığın yayılıp yerleşmesi esnasında ortaya çıkmış, bir nevi halk edebiyatının tarihi romanları olarak nitelendirilen Battal Gazi ve Danişmend Gazi Destanı'nda da çok eşle evliliğin örnekleri görülür. Battal Gazi unvanıyla anılan Cafer, önce amcasının kızı Zeynep'e âş̧ı olur ve evlenir. Zeynep Hatun'un Rum'a esir düşmesi üzerine onu kurtarmaya gider ve bu sırada Rum kayserinin ortanca kızı Mâhpiruz'u alır. Çünkü Mâhpiruz, rüyasında kendisine Müslüman olmasını ve Cafer'le evlenmesini ögütleyen Hz. Muhammed'i görmüştür. Battal, daha sonraları kâfir Taryun'un Müslümanlığı seçen kızı Gülendam ile evlenir.

Erali ve Şirali Destanı'nda Kara Han'ın çok eşli olduğu destanda geçen “Kara Han büyük küçük herkesin duasını alıp, en büyük karısının kulübesine gitti." cümlesinden anlaşılmaktadır. Aynı destanda Gülmastura kuması Gülçehre için yalancı gül tabirini kullanması toplumun kumaya olan bakışını yansıtması bakımından önemlidir.

Köroğlu'nun Özbek varyantlarında çok eşli olduğu görülür. Eşleri Ağa Yunus Peri, Miskal Peri ve Gülnar Peri adıyla anılan ve Köroğlu'nun bin bir zorlukla uzak diyarlardan getirdiği peri soylu güzellerdir. Bu peri soylu güzeller, Köroğlu'na müşkül durumlarında yardım eli uzatır; Köroğlu'nun yokluğunda Çambil ilini bir hükümdar gibi yönetirler. 
Bazen destanlarda kadınların sevdikleri erkekleri bir başka kadınla paylaşmayı kabul edecek kadar fedakâr oldukları görülür. Bunun en güzel örneğini Erali ve Şirali Destanı'nda görmekteyiz. Akılay kocası Şirali'nin Afitabay adlı peri padişahının kızına âşık olmasını ve hatta üzerine kuma gelmesini anlayışla karşılar: "Akılay: - Afitabay denilen peri padişahının kızıdır. O size âşık olduysa, on tane (kadın) alsanız da bana bir zararı yok. Asşıklık dünyanın en kötü şeyidir. Aşk ateşiyle yakmadan elbette gitmeniz gerek, böyle padişahın kızı size âş̧ı olduysa, onu almanız gerekir, dedi." (Fedakâr, 2009, s. 321)

\section{Karakter Özellikleri Bakımından Destan Kadınları}

\subsection{Akıllı Kadınlar}

İncelenen destanlarda aklın ve sağduyunun temsilcisi olarak öne çıkan kadınlar vardır. Bu kadınların aynı zamanda sezgileri de güçlüdür. Erali ve Şirali Destanı'nda Afitabay, Akılay'ın çok akıllı bir kadın olduğundan bahseder ve kendisi de Şirali ile evlenerek Akılay ile kuma olmayı makul bulur.

"Bazılarının dostu ile yâri var,

Akılay'da otuz kadinın aklı var,

Bu ablamı yakamam teyzeciğim,

Onun baldan tatlı huyu var." (Fedakâr, 2009, s. 377)

Melike Ayyar Destanı'nda Melike'nin arkadaşı Tillekız, kalenderlerin yaptığı altın aslanın canlı olmadığını ve babası Akdevşah'ın getirdiği yüzüğün tılsımlı olduğunu fark edebilen son derece akıllı bir kadındır: "-Ey Hadiçe cariye, burada çok durma, benim söylediklerimi sahibene söyle. Gelenler kalender değil, hilekârdır. Aslanı yapan kalender değil, o da sihirbaz hilekârdır. Aslanın canı yok. Aslanın canı Göroğlu'nun oğlu, Avazhan'dır. Aslanın canı var diye Melike Ayyar'ın, Avazhan yârine binerek rezil olmaktadır. Benim sözüme inanmiyorsan, git o aslana tekme at. Ben gelmem, sözlerimi Melike Ayyar'a gidip ilet, diye Hadiçe'yi gönderdi."(Yücel, 2007, s. 199)

Ayçınar Destanı'nda başkahraman Ayçınar, Kettepay ilinin en zengini olan ve aynı zamanda çalışanı oldukları Nazarbay'a bile karşı koyabilen akıllı ve zeki bir kadındır. Nazarbay'la evlenmek istemeyen Ayçınar, dünürcülerden öyle bir başlık ister ki Nazarbay'ın bunu yerine getirmesi imkânsızdır:

"Ey klzım! Aklın yerinde mi, yoksa birine mi verdin? Bu ne demek oluyor? Ben nice yerlere dünürcü gittim, ne kizların ne dulların kendi başllğııı kendinin söylediğini işittiğim olmadı. Peki, tamam. Sizlerde "Kızın kendisi başlı̆̆ını ister." sözünü doğru kabul edelim. Sayısız koyunlar, keçiler, atlar, develer; altınlar, gümüşler, ziynetler dururken olmayacak şeyleri isteyip de ne yapacaksın?! On tane kuzu, bu da laf mı yani, onu ne yapacaksın?! Otuz tane aslan. Yoksa onları bağlatıp böğürtecek misin? Kırk tane kaplanmış! Onları bağlatıp dişlerini mi sayacaksın? Elli tane aygır, bu olur: binsen çok, satsan para; altmış beş tane öküz, bunlarla çift sürülse de, satılsa da olur. Seksen tane teke bir çepişe gerektir mi diyorsun? Çepiş onları ne yapacak? Tekenin çepişten farkı var mı? Onun yerine teke isteseydin ya. Doksan tane tahtayı ne yapacaksın? Yabanilere ev mi yapacaksın?" (Solmaz, 2007, s. 39)

Ayçınar'ın bu isteklerini yerine getirmek üzere Nazarbay, Babür Şah'ın kapısını çalar. Ayçınar'ın istediği başlıkları sıralar. Bunun üzerine Ayçınar'ın Nazarbay denilen ihtiyarla evlenmek istemediğini sezen Babür Şah Ayçınar'ın Allah vergisi aklına, zekâsına hayran kalır:

"Neysen de seni önce görmüş

Senin gibi ihtiyarın burada bahtı kurumus,

Klz olsa da aklina hayranım,

Bilgeliği ona Huda vermiş." (Solmaz, 2007, s. 59)

Dalli Destanı'nda Hasanhan, Dalli'yi bir oyuna getirip atının üstüne bindirmeyi planlar. Han Dalli'nin köşkünün altına atıyla varır. Han Dalli'ye atı satın almak isterse parasını kendi eliyle vermesini ister. Han Dalli "Bırak ya, elimi uzatmayacağım, bileğimden tutup atının sırtına atsa, razı olmayınca döve 
döve götürse ne yaparım?" diye bunun bir hile olduğunu anlar ve kabul etmez. Hasanhan bu kurnazlığın Han Dalli’ye işlemediğini görür.

Han Dalli babasının askerleri ile savaşan Hasanhan'ın moral ve motivasyonunu yüksek tutmaya çalışan, sağduyulu ve zeki bir kadındır. Hasanhan'ın güç kaynağıdır. Bu süreçte birbirlerine destek olurlar: "Han Dalli çok zeki kız idi. Hasanhan'ı üzmeyeyim diye çok ilgilendi. Her yerden güzel hikâyeler anlatıp gülerek, bel kırarak, kaş çatarak, dudaklarını bükerek nazlı durup Hasanhan'ın her yönden gönlünü aldl, beğeneceği sözleri seçip konuşarak, avutup pehlivanı asla üzmedi. Her yiğidin makbul yâri olursa, aklı şuuru varsa erini asla üzmez. İște Han Dalli çok bilgili, geniş fikirli, ögüut verici, çok terbiyeli kız idi. Hasanhan'ı yalnız diye hep isteğine baktı, aslı kurnaz klz. Hasanhan da Han Dalli'nin cemaline, letafetli kemaline âşık olup hayran hayran oturdu."(Sezer, 2017, s. 225)

\subsection{Alp Kadın}

"Doğu ve Batı destanlarında bahadır kadın tipi ayrıntılı işlenmiştir. Rus destanlarında polyanitsa, Yunan mit ve destanlarında amazon, güney Slav halklarında gayduk, Türk halklarında alp-kız olarak adlandırılmaktadır. Bu alp kadın tipleri çoğu anlatıcıların bahadır kadın tiplerini yaratmak için geleneksel bir kurala bağlı kaldıklarını kanıtlamaktadır. Hatta tarihte adı geçen yönetici kadınların yaptıklarını anlatan tarihî destanlarda da arkaik kahramanlık destanlarındaki bu kuralların kullanıldığııı görmek mümkündür.”(Temur, 2012, s. 132)

Türk destanlarında kahraman (alp) tipinin örneklerine Ŏguz Kağan, Manas, Dede Korkut ve diğer Türk boylarının destanlarında rastlıyoruz. Sürekli hareket halinde ve aktif olan uygarlıklar için bu durum son derece doğaldır.

"Destanlar ve destancılık konusunda en belli başlı eserlerden biri sayılan Özbek Halk Kahramanlık Destanları isimli eserde Prof. V. M. Jirmunskiy ve H. T. Zarifov, Özbek halk destanları ve onların ortaya çıkışı konusunda görüşlerini belirterek Barçın, Yunus Peri, Gülçehre, Gülihiraman ve Arzıgül gibi halk edebiyatının malı olmuş kahraman kızlar hakkında şöyle demektedirler: “...halkların kahraman kızları konusundaki destanlar geleneksel anaerkil dönemin hayat tarzıyla sık1 sıkıya bağlantılıdır. Anaerkil ziraat döneminde, hayvancılıkla iştigal eden göçebe döneme nispeten kadınların daha özgür bir hayat tarzına sahip olmaları, onları erkeklerle yan yana, bazen de bağımsız olarak savaşlara katılmaya zorladığından kahraman kadın tiplerinin ortaya çıkmasında gerekli zemini hazırlamıştır." (Galima, 2001, s. 47)

Alpamış Destanı'nda Berçin alp tipine uygun biçimde, Bayçibar'ın toynağındaki çivileri başörtüsü yardımıyla dişleyerek çekip çıkaracak derecede güçlü kuvvetlidir:

"Çeliği eritir klzların nefesi,

Berçinay bakarak düşünüyor,

Vurduğu çivi yassı dize ulaşmış,

Baş örtüsünü toynağına koydu,

Çivileri dişleyip çekip çıkardl.’'(Canpolat ve Öz, 2000, s. 188)

Yine aynı destanda Berçin, Alpamış ile Kökeldaş'ın güreş ettiği sırada Alpamış'ın yenemeyeceğini düşünüp Kökeldaş'la kendi güreşmek ister:

"Ylkamazsan, beyim, verin bana strayl,

Erkek klyafetlerini ben giyeyim,

Var gücümü bileğime vereyim,

Bu Kalmak'ı pare pare yapayım.

Kızlar size kadınsı diye söyler

Kızların söyledikleri bana batar. 
Uzun güreşip, kendinizi avare etmeyin,

Kız çocuğu diye beni güçsüz sanmayın." (Canpolat ve Öz, 2000, s. 197)

Dalli, Gırgök ata biner, "Hayvancağızım, kadın bilme, er bil/Benim gönlümü kendin ile bir bil." der. Bu özellikleriyle Dalli han tipi, Dede Korkut’taki Selcen Hatun'u ve Köroğlu'nun eşi Telli Nigar'1 hatırlatmaktadır. Hasan Bey, Akşehir beyinin kızı Telli Nigar'ı kaçırırken yaralanır. Bunun üzerine Telli Nigar, Hasan Bey'in kıyafetlerini giyerek onun Aşkardora isimli atına biner. Yedi kardeşi ve nişanlısı Arap ile savaşır.

Zülfizar Destanı'nda Avazhan düşmanla mücadele ettiği sırada yaralanır. Bunu gören Zülfizar, Avazhan'ın kıyafetlerini kendisi giyer, yılandilli keskin kılıcı beline asar. Kalkanını ve çelik okunu eline alır. Gırat'ın üzerine binerek silahlarını hazırlar. Avazhan'a şu sözleri söyler:

"Hanım, beyim kendini sıkmayasın

Nadan gönlünü her hayale bölmeyesin!

Kadın diye bizleri namert bilmeyesin

Burakıp giderim diye alınmayasin

İyilik göresin, kötülük görmeyesin

Hayaline kötülü̈̆̈̈ almayasin

Bırakıp gider diye şüphe duymayasın

Ben gitmezsem gelip kalır düşmanlar

Gönlünü bölme yiğit cengâver!

Kan döküp gelecek yârin Zülfizar

Ben gelene kadar dua et, sultanım!' (Çolak, 2001, s. 344-345)

Destanlarda karşılaşılan bu örnekler, destan kadınlarının düşmanlarını yenme esnasında gösterdiği mücadeleci ruhu, daha da önemlisi çeviklik, kahramanlık ve fedakârlık ruhunun kimi zaman erkeklerden de üstün olabileceğinin en açık göstergesidir.

\subsection{Bilge Kadın}

Bilge kadın, aynı zamanda kocasına ve oğluna öğütler vererek onları her türlü tehlikeye ve düşmanlara karşı uyanık olmaya davet eden kadın demektir. Alpamış Destanı'nda Berçinay, Kalmuk iline göç etmeye hazırlanan annesine seslenir:

"Şeyh gelirse karşılar müridi,

Hatun değil midir erin veziri?!

Kocaya tavsiye verilmez mi,

Danışarak yönetilmez mi?

Zengin babama, bey amcama ne oldu,

Nasihat etmedin biçare anneciğim"(Canpolat ve Öz, 2000, s. 38)

sözleri toplumun kadının bilge bir tavır takınarak ailede müşkülleri çözen bir görev üstlenmesi beklentisinin açık bir ifadesidir.

Destanlarda anneye düşen görevlerden biri de çocuklarının eğitilmesini, onların hüner ve erdem sahibi bireyler olmasını sağlamaktır. Hadi Zarifov, Alpamış Dastanining Esasiy Motivleri Hakıda (Zarifov, 1957) adını taşıyan çalışmasında çocukları okutma motifinin Özbek halk destancılığında dikkat çekici olduğunu belirtmiştir. Bu gelenekte geleceğin kahramanlarını yetiştirmek üzere çocuklar anne baba kontrolünde dört beş yaşlarında okula götürülür. Tarihçilerin de ifadelerine göre Orta Asya'da okuma yazma öğrenmek Araplar gelmeden önce popüler olmuş ve çocuklar beş yaşında iken hesaplama ve yazmayı öğrenmişlerdir. Diğer taraftan Abbasiler döneminde el-Mutasım'ın eşi, Türk anası Şuca 
Hatun'un oğlu el-Mütevekkil (Cafer)'in ilk ve temel eğitimini annesinden aldığı; bu eğitimin Halifelik dönemi icraatlarına esas teşkil ettiği bilinmektedir. Tıpkı bu örnekte olduğu gibi Erali ve Şirali Destanı'nda kahramanların annesi Gülmastura oğullarının ilim, irfan öğrenmesini isteyen akıllı, düşünceli ve bilgili bir kadındır. Oğullarını daha dört yaşında iken mollaya verir. Bu aynı zamanda kahramanın anneden kopuşunun da örneğidir. Bu noktada Freud'un bütün kaygı anlarının, anneden ilk ayrılış anının- doğum anında soluğun sıkışması, kanın hücum etmesi vb.- acı dolu hislerini yeniden ürettiğini öne sürdüğü fikirlerini akla getirmektedir. Türk mitolojisinin en anlamlı öykülerinden biri olan Ergenekon da adeta anneden kopuşun simgesel bir örneğidir.

"Okumayan sonunda olur derbeder

Okumayan kişi sopaya benzer,

Hoca ilminize kurban olayım,

İyice okutun, böylesi muteber.

Okutun keskin olsun dilleri,

Kaleme yakışsın nazik elleri

Ata binince açı olsun yolları

Bu ikisi Kara Han'ın oğulları.

Okutmaya anasinın oldu ricast,

İkisini okutun uygundur zaman,,

Alıp gelen anasının dökülsün günahı." (Fedakâr, 2009, s. 63)

Rüstem Han Destanı'nda Hürayim'in devlet yönetimindeki danışmanı konumundaki Hımça Hatun ilahi sezgi gücüne sahip, bilge bir kadındır. Hürayim'in başarılı devlet yönetiminde Hımça Hatun'un katkıs1 büyüktür. Aynı zamanda rüya yorumlama özelliği Hımça Hatun'un bilgeliğinin bir göstergesidir. Hürayim bir gece rüyasında üç yüz altmış cellatın kendisini kamçıladığını görür ve bunu Hımça'ya anlatır. Hımça Hatun bu rüyayı şu sözlerle yorumlar:

"Rüyanı anlattın abla, yüreğim sızladı,

Aktaş şehrinden senin rızkın kesildi.

Anladım, göremeyeceksin biricik kuzunu

Gel avare abla, beraber ağlayalım şimdi!

Şöyle olaylar girmiş senin rüyana:

Gün geçmeden, cellatlar gelecek karşına.

Bu rüya, şu olacaklardan veriyor haberi:

Cellat geliyor, abla, oyalanma şimdi,

Bir düşmanın yaplyor sana bu işleri,

Gelip bağlayıp buradan alacaklar seni.

Bilmem nerelere alp gidecekler seni,

Seni mahvedecekler kesip başını.

Ömrünün sonu şimdi gelmiş gibi,

Gel, abla, beraber ağlayalım şimdi!" (Fedakâr, 2016, s. 65)

Destanlardaki Hımça Hatun gibi kadınların rüyaları yorumlaması, onların tefekkür ve muhayyile güçlerinin derecesini anlama ve fantastik kabiliyetleri açısından büyük bir öneme sahiptir. 


\section{Fiziksel Özellikleri Bakımından Destan Kadınları}

\subsection{Güzellik Unsurları}

Kadınların güzelliği, fedakâr ve vefakâr olması, zekiliği ve yaratıcılığı sanat ve edebiyat ürünlerinde, özellikle halk edebiyatında, övgülerin merkezi olmuştur. Güzel olarak addedilen her şey kadınları sembolize eden birer unsur olagelmiştir.

Özbek destanlarında sevgili, eş ya da anne rolündeki kadınlar, soylu ve güzel kadınlardır. Bunlar, yaşadıkları yerde güzellikleri ile nam salmıştır. Destan kahramanının da bu soylu ve güzel kızı iline getirmek üzere yani "sevgiliye ulaşma" maksadıyla zorlu bir yolculuğa çıktığ görülür. Belagerdan Destanı'nda Avaz, Akkız adlı periyi görür ve onun bedenine bakarak: "Olgun elma gibi tam kızarmış, zülüfleri beline inmiş, niceleri cemalini görse, aklı şaşarmış." diyerek güzellik anlayışını ifade eder. Huşkeldi Destanı'nda Göroğlı Bey büyük hanımı Ağa Yunus Peri'ye: "Kaşların kalemdir/ Yüzlerin aydır/ Suretin cemalin boz doğandır." benzetmelerini yapar.

Özbekistan sahasında Göroğlu adıyla anılan Köroğlu Destanı'ndan doğmuş, aşk- kahramanlık konulu bir destan olan Melike Ayyar Destanı'nda, Melike Ayyar "kuğu boyunlu, âfetican, badem dudaklı bir acayip nazenin" peridir. Göroğlu Sultan onu görür görmez âşık olur. Melike Ayyar Destanı'nda Avazhan, Melike'yi “giydiği gülgûn kırmızı, aklını alır ahu gözü” sözleriyle; Tillekız'ın nice cariyesinden biri olan Akkız ise "veresiye değil, nakit kız; tembel değil, sağlam kız; uzun değil, orta boylu tam kız; dişleri pirinç gibi ak kız, kaşları kalem, kendisi iyi, berna, güzel." şeklinde tasvir edilir. Erali ve Şirali Destanı'nda peri padişahının kızı Afitabay'ın haklı bir şöhrete sahip güzelliği, kuması Akılay tarafından samimi bir üslupla övülerek yüceltilmiştir:

“Alip vereyim size keremli sultan,

Allemde yok böyle gözleri çolpan,

Dişleri inci gibi, güzelliği pek yaman,

Bunu bil törem, iffetlidir Afitabcan!" (Fedakâr, 2009, s. 373)

Destanlarda güzelliği tasvir edilen kadınların bir özelliği de ay gibi bir yüze sahip olmalarıdır. Alpamış Destanı'nda Kalmak Şah'ın çobanı Keykubad şahın kızına âşık olur. Onun yüzü adeta bir "mah-1 enver" dir:

"Teke alıp getirdi, bir mâh-ı enver,

Huzurunda saf saf cariyeler,

Ben de anladım, Tavka'nın gönlü var,

Şah kızına oldu talip.

Parayı verip kendi sürünür,

Görünce kalmadı içimde dert,

Ben anlamamışım, o da bana intizar,

Naz ile söylemiştir o, bir nice söz."(Canpolat ve Öz, 2000, s. 309)

Destanlarda kadınların kaş, göz, saç, yanak gibi güzellik unsurları yanında güzel kabul edilen kadının en belirgin özelliği endamlı olmasıdır. Endamlı olmayı sağlayan ilk fiziksel unsur da uzun boydur. Dalli destanında Erzurum padişahının kızı Dalli'nin güzelliği ve şöhreti tüm dünyaya yayılmıştır. $\mathrm{O}$ kadar meşhur olmuş ki dünyada insanlar arasında onun gibi hoş edalı, boylu poslu, huri misali kız yoktur. "Bugünlerde dokuz kat örtü örter yüzüne; ayı söndürür, gündüzü karanlık eder, diye meşhur olmuş."

Özbek destanlarında kahramanın uğruna savaşlar yaptığı güzellerin ünü dünyaya yayılmıştır. Küntogmuş Destanı'ndaki Helbeka da böyledir: "Helbeka on dört yaşından sonra ünü dünyaya yayıldı, Dağıstan'1 geçti. Helbeka'nın tasvirini, çekici güzelliğini işiten padişahlar ve hanzadeler her memleketten, her yurttan, her diyardan sözcü gönderiyordu.”(Akbay, 2010, s. 23) 


\subsection{Giyim Kuşam ve Süslenme}

Toplumların yaşama biçimini belirten göstergelerden biri de giyim kuşamlarıdır. Doğa şartlarından korunma ihtiyacından doğmuş olan giyim kuşam; iklim, aile, eğitim, ekonomi, gelenek görenekler, âdetler, din ve inanışlar gibi etkenlerle, bugün de olduğu gibi, tarihsel süreçte değişime uğramıştır. Yüzyıllar boyunca kültürel, ekonomik ve askeri dinamizmini kendi kurdukları devletlerle taçlandıran Türklerin giyimi konusunda tarihi kaynaklardan elde edilen bilgiler sınırlıdır.

Özbek Türklerinin geleneksel kadın giyim kültürü içerisinde başlıkların önemli bir yeri olduğu görülmektedir. Nitekim Ayçınar Destanı'nda Halyar'ın, kızı Ayçınar'a nazar değmemesi için başına "todana" adıyla taktığı taç bir aksesuar olmanın yanı sıra Özbek Türklerinin inançları da yansıtır. Todananın, kem gözlerden korunmak için kadının başına taktığı bir tılsım olduğu görülür.

"Tarihçilerin belirttiklerine göre Türk kadınları savaşa giderken dahi makyaj yapmayı, takılarını takınmayı ihmal etmemişlerdir." (Galima, 2001, s. 38)

Güzellik kavramı ile insan arasında daima bir ilişki olmuştur. Bu nedenle tarihin her döneminde, o dönemin estetik anlayışına uygun biçimde güzel olmak, güzel görünmek ve güzel kalmak insanlar için önem arz etmiştir. Kadınlar ise erkeğe göre güzel görünmeye ve süslenmeye daha çok önem vermiştir. Çevrelerindeki insanların ve özellikle karşı cinsin beğenisini ve övgüsünü kazanmak isteyen kadınlar, güzelleşmek için birtakım yollara başvurmuştur. Daha Sümerler döneminde bir kadının süslenmeye olan düşkünlüğünü, günümüz kadınından pek de farklı olmayacak biçimde, Aşk tanrıçası İnanna'nın kardeşi ile olan şu konuşmaları ortaya çıkarmaktadır:

“Aşk Tanrıçası İnanna sevgilisine gitmeden önce süsleniyormuş. Kardeşi İnanna’ya soruyor:

Kardeşim niçin eve kapandın?

Kardeşi cevap veriyor:

Kutsal leğen içinde yıkandım

Arı kap içinde sabunlandım.

Göğün kraliçelik elbisesini giydim

Gözlerimi kömürle boyadım.

Kokulu saçlarımı koyuverdim.

Kıvırcık dudaklarımı süsledim

Buklelerimi enseme dünürdüm.

Koluma gümüş bir bilezik geçirdim

Küçük boncukları boynuma taktım.

İste bunun için ben evdeyim.

İnanna yeraltı dünyasına giderken de süsleniyor. "O kırların tacı Şugurra'ya başını koydu. Saçının siyah buklelerini alnına indirdi. Mavi küçük taşları boynuna bağladı. İki sıralı kolyeyi göğsüne sarkıttı. Krallık elbisesini vücuduna sardı. Gözlerine- 'o (erkek) gelsin, o gelsin' adlı sürmeyi çekti. Göğsüne 'adam gel gel' adlı broşunu taktı. Bileğine altın bileziğini geçirdi.” (Gültepe, 2013, s. 77-78)

Özbek destanlarında sözü edilen kadınların giyim kuşamlarında tercih ettikleri kumaş veya kıyafetler, renkleri, biçimleri, aksesuarları ve mücevherleri; bunların yanı sıra çeşitli süs malzemeleri kadının güzelliğine güzellik katan unsurlar olarak yerine göre destanların mevzuu olmuştur. Yüzyıllar boyunca çeşitli uygarlıkların gelip geçtiği, İpek Yolu'nun üzerinde bulunduğu Özbekistan, adeta giyim kuşam kültürünün birikim merkezi olmuştur. Bu birikimin şekillendiği, geleneksel giyimin muhafaza edildiği, zengin giyim kuşam unsurlarının köklerini belirten kaynaklardan birisi de destanlardır.

İncelediğimiz destanlarda padişahların kızları ve hanımları çoğunlukla ipek, kadife gibi değerli kumaşlardan yapılmış giysiler giyerken cariyelerin daha harcıâlem kıyafet ve takılar kullandığı 
görülür. Rüstem Han Destanı'nda Hısrav Şah'ın kızı Aftabay değerli kumaşlardan yapılmış kıyafetler giyer.

“Aftabay'ın kemali,

Aydan üstündür cemali,

Onun başında uçuşur,

İpek dokuma yemenisi." (Fedakâr, 2016, s. 187)

Saf aşk konulu destan olarak nitelendirilen Küntogmuş'da Helbeka'nın giyim kuşam ve süslenmesi ile ilgili olarak şu satırlara yer verilir: "Padişah davulu vuruldu, kızlar da aşağıya doğru yürüdü, gelip has menzile girdi. Helbeka, altın kemerli köşklerini süsleyip, kırk kızını alara, şahane elbiselerini giyip, kendini süsledi." (Akbay, 2010, s. 38)

Göroglinin Tugilişi'nde Göroglubek'in Ağa Yunus ve Miskal perilerin cariyesini tasvir eden sözlerinden Özbek kadınının kıyafetlerine dair ayrıntılar bulmak mümkündür: "O zaman Göroglubek baksa, İrem bağının kapısı açılmış, bir uzun saçlı, ince belli, kalem kaşlı, beyaz göz kapaklı, ak kemzullü, düğmeli kevuşlu, hafif meşrep bir cariye çıkıp gelmektedir.”(Çelikbay, 2000, s. 446-447) Kevuş, deriden dikilen ve genellikle mest ile giyilen bir tür ayak giyimi iken kemzul yazın kullanılan yensiz, uzun üst giysisidir.

Si-An'dan Tiran'a Tarihi İek Yolu isimli eserinde Yahya Aksoy (2015, s. 124) 1990'll y1llarda Özbekistan'ın Taşkent, Semerkand, Narpay, Karş1, Nevai, Hatırc1, Aktaş, Pestrgan ve Bulungur şehirleri ve çevresinde kadın kıyafetleri üzerinde araştırmalar yapıldığını ifade etmiştir. Bu seyahatlerden elde edilen veriler destanlarda maddi bir kültür ögesi olarak karşılaşılan geleneksel giyim kuşam özelliklerinin yirminci yüzyılda Özbekistan'da kadınlar arasında halen varlığını sürdürdüğ̈̈nü kanıtlamaktadır. Özbekistan'da kıyafetlerde özellikle atlas ve zar atlas dokumacıllı̆ın geniş yer tutuğu, genç kızların firfırlı ve süslü köylek (elbise) ve kırmızı kadife kumaştan dikilmiş nimçe (kısa yelek) adı verilen kıyafetleri giydikleri, ayaklarına ise tüfli adı verilen topuklu ayakkabı veya çizme kullandıkları Aksoy'un verdiği bu bilgiler arasındadır. Ayrıca, destanlarda kahramanların sıkça kullandığ 1 bir şapka türü doppa aksesuarlar arasındadır. Sırga adı verilen küpeler, zibi gordonnazgerdan denilen kolyeler takmaktadırlar. Evli kadınlar saçlarını bir ya da iki örgü yapıp çömelek (işlemeli saç bağı) ile süslemektedirler. Gelinlerin ise saçlarını birden çok örgü yapıp tahta pupek adlı bir saç süsü taktıkları ve bu süsü kırk gün boyunca taşıdıkları bilinmektedir.

\section{SONUÇ}

İnsanlık hiç kuşkusuz kadının toplum içerisindeki varlığını çok geç dönemlerde fark edebilmiştir. Hâlbuki mitik tefekkürde Tanrı'ya yaratma ilhamını veren, ilkel bahçe tarımı ile uğraşan, ormanlardan bitki ve meyve toplayan, hayvanları ehlileştiren, ticaret yapan, devlet idaresinde roller üstlenen kadındır. Şemseddin Sami'nin güzel teşbihiyle galaksilerin güneşin etrafında dönmesi gibi aile üyelerinin etrafında bulunduğu ailenin temel direği makamında olan yine kadındır.

Destanlarda tasvir edilen kadınların, tabiatı kontrol altına alma, insanoğlunu medeniyet yoluna sevk etme ve üretme gücünde öncü olma gibi yadsınamaz katkılar sağladığı görülür. Bu durum masal, efsane ve rivayet gibi sözlü edebiyat ürünleri için de geçerlidir. Dolayısıyla bu ürünlerdeki kadınların uydurma ve hayal mahsulü olduğu; hiçbir tarihi temelinin olmadığ 1 düşüncesi konuya dar açılı ve eksik bir bakış olacaktır. İncelenen destanlardaki, aktif ya da pasif, her kadın Özbek insanının hayata farklı bakış açısını ve toplumun değişim ve gelişim seyrini ifade etmektedir. Ayrıca bu kadın unsurlar Özbek kadını ile ilgili ilk fikirleri vermeleri bakımından da oldukça değerlidir.

Destanlarda çoğunlukla erkeklere yüklenen savaşçılık ve kahramanlık vasıflarının kadınlarda görülmesi çalışmanın önemli sonuçlarından biridir. Destanlarda tespit edebildiğimiz kadarıyla annelik rolünü üstlenen kadınlar destanın başında çocuk sahibi olma sürecinde, çocuğunu besleyip büyütüp kahramanın anneden ilk ayrılışına kadar olan süreçte, göçebe kültür tarzını yansıtan kahramanlar olarak karşımıza çıkarlar. Destanlarda anne rolünü üstelenen kadınların, annelik içgüdüsü aşırı gelişmiştir. 
Destanlardan elde edilen veriler incelendiğinde Özbek toplumunun aile ve evlilik kurumuna bakış açısı, iki cins arasındaki ilişkilerin gelişim çizgisi, Özbek toplumunun bu konulardaki normlarının açık ve net bir biçimde söz konusu ürünlere yansımıș olduğu görülür. Alpamış Destanı'nda Berçin'in evleneceği erkeği seçmek için yarışma düzenlemesi kadının sahip olduğu özgürlük ortamını göstermede örnek teşkil etmektedir.

Kahramanların eş seçimi ve evliliğin kurulma aşamasında kadınlardan beklenen erkeğin beğenisini kazanacak kadar güzel ve alımlı olmasının yanı sıra asil, iyi huylu, namuslu ve becerikli olması gelmektedir. Bazı anlatılarda kahramanın evleneceği kızın Müslümanlığı kabul etmiş olması da aranan özelliklerdendir.

Özbek sahasında yaratılan Türk destanlarında tasvir edilen kadınların Türk kültür tarihî gelişim çizgisine paralel olduğu görülür. Bu bağlamda eski Türk töresinin ve değerlerinin hâkim olduğu hem göçebe ve yarı göçebe hayatın temsilcisi alp kadınlar hem de İslamiyet'in ve yerleşik düzenin etkisiyle daha pasif kadınlar karşımıza çıkar. Destanların oluştuğu siyasi, tarihi, dini, sosyal şartlar göz önüne alındığında kadın kahramanların bu değișkenliği göstermesi son derece doğal bir durumdur. Dalli, Melike Ayyar, Huşkeldi ve Belagerdan gibi kahramanlık- aşk konulu destanlardaki kadın kahramanlar içe dönük ve pasif kişiler olarak sunulmuştur. Bu kadın kahramanlar herhangi bir şehrin uzak bir köşesinde kendine ait geniş bahçeli saray veya köşklerde kırk cariyesi ile birlikte yaşar. Erkek kahramanın kendisini kötü huylu devlerin ya da öldürülmez ejderhaların elinden almasını beklemektedir. Bu durumun kadının alplik yönünü zayıflattığı söylenebilir. Bu kadınlar bize Dede Korkut Hikâyeleri'ndeki Bamsı Beyrek ve Kan Turalı'nın evlilikte tercih etmediği "cici bici Türkmen k1zları"nı hatırlatır.

Özbek destanlarında tasvir edilen kadın kahramanların-farklı kültür muhitlerine ve coğrafyalara dâhil olma neticesindeki değişme ve gelişmeye rağmen- Dede Korkut Hikâyeleri'nde çizilen kadın tiplerin temeli üzerinde yükseldiği şüphesizdir. Sözgelimi, Alpamış Destanı'nda Berçin, evleneceği erkeğin kuvvet ve cesaretini denemeyek isteyen Banı Çiçek ve Selcen Hatun'la; çocuğunu koruyup kollaması ve namus kavramına olan hassasiyeti dolayısıyla Burla Hatun'a yaklaşmaktadır. Dolayısıyla çalışmada Özbek destanlarında yer alan kadın unsurunun incelenmesi ile ortaya çıkan değerlerin, Türk dünyasının diğer boylarına ait destan metinleriyle mukayese edildiğinde ortak nitelikler taşıdığı görülür.

Kadınlar yeri geldiğinde kahramanın annesi sıfatıyla onları eğiten olgun ve bilge kişi, eşi sefere çıktığında ülkeyi idare eden bir yönetici ve tecrübî yaşamdan gelen bilgileriyle donanmış haliyle eşlerine yol gösteren bir rehberdir. Bu yönüyle Özbek destanlarındaki kadın kahramanların Türk destan dünyasındaki diğer kadın kahramanlarla belirgin ölçüde benzeştiği ve bütüncül bir yapıya sahip olduğu sonucuna varılmıştır.

Destanlarda kadın kahramanların dış güzelliklerine, süse, ziynete, dünya güzelliklerine ve gösterişe düşkün oldukları anlaşılır. Ancak, giyim kuşamla ilgili ayrıntılı anlatımlara yer verilmediği görülmüştür. Kadının olağanüstü güzellikleri çeşitli benzetmelerle destan metninin manzum kısımlarında dile getirilir. Destanlarda fedakârlığı, vefası, yiğitliği ve merhametiyle toplumsal hayatta kendine yer edinmiş ve kendini kanıtlamış olan Özbek kadını güzelliğini ve aklını kullanarak birçok işi başarıya ulaştırır.

Destanlarda icrayı kolaylaştıran, kadın kahramanların niteliklerini sayarken kullanılan epitetler vardır. "ay yüzlü" "baldudaklı" "ince belli" "kaşları keman" "dudağı şeker" "kara gözü sürmeli" "dal gibi boylu" "gül yüzü bostan" "selvi boylu" "saçları kunduz" "gözleri yıldız" "dolunay yüzlü" "nazik belli" "altın kâküllü" " gözleri şehla" "kaşı kalem" "cemali güneşli" "cemali aylı" "geniş kucaklı" gibi çok sayıda epitet kullanılmıştır. Yüz için güneş ve ay benzetmeleri yapılmıştır. Diş̧ler inci/sedef, saçlar sümbül, boy selviye teşbih edilmiştir. Bütün bu epitetlerden ortaya şu sonuç çıkmaktadır: Güzel kadın anlayışı coğrafya ve zamana göre farklılık gösterir. Ancak Türk dünyasının hemen her yerinde ve her dönemde Türk kadını için güzellik algısı sabittir. O, selvi boylu, ay yüzlü, kırmızı yanaklı, kara gözlü, uzun kirpikli, saçları uzun ve kâküllü bir varlık olarak tasvir edilmiştir.

Destanlarda kadınların giyim kuşam ve süslenme tercihlerinden verilen örneklerin Özbek Türklerinin zengin kültür değerlerini tanımak ve korumak adına önemli olduğu sonucuna varmaktayız. Özbek 
destanlarındaki kadın kahramanların yaşam felsefeleri, yaşadıkları coğrafya, yaşı, unvanı ve inançlarına göre değişim gösteren giyim anlayışları çok renkli, çeşitli ve motiflidir. Özellikle hükümdar kızlarının giydikleri kıyafetler altın işlemeli, ipekten atlas vb. değerli kumaşlardan ve simlidir. Kadınlara özgü giyimin başköşesinde ipek olması, Özbekistan topraklarının İpek Yolu üzerinde olmasının tabii bir sonucudur.

\section{Bilgilendirme / Acknowledgement:}

1- Bu makale, Özbek Sahası Türk Destanlarında Kadın başlıklı doktora tezinden üretilmiştir.

2- Makalemizde döküman analizi yöntemi uygulandığından etik kurulu izni ve/veya yasal/özel izin alınmasını gerektiren bir durum yoktur.

3- Bu makalede araştırma ve yayın etiğine uyulmuştur.

\section{KAYNAKÇA}

Akbay, D. (2010). Özbekçe Küntugmiş destanı. Yayımlanmamış yüksek lisans tezi, Anadolu Üniversitesi, Eskişehir.

Aksoy, Y. (2015). Si-An'dan Tiran'a tarihi ipek yolu. İstanbul: Boğaziçi Yayınları.

Alimoğlu, S. (1997). Özbek folklorunun tür hususiyetleri. Türk Lehçeleri Ve Edebiyatı Dergisi, 12, 57-59.

Campbell, J. (2018). Kahramanın sonsuz yolculuğu. Sabri Gürses (Çev.), İstanbul: İthaki Yayınları.

Çelikbay, A. (2000). Göroglinin Togilişi destanı- Özbek varyantı (inceleme-metin-dizin-çeviri-ek. Yayımlanmamış yüksek lisans tezi, Ankara Üniversitesi, Ankara.

Çolak, H. (2001). Özbek kahramanlık destanı Zülfizar. Yayımlanmamış yüksek lisans tezi, Ege Üniversitesi Sosyal Bilimler Enstitüsü, İzmir.

Çolak, İ. (2017). Özbek Türklerinin 'Şeker Bilen Şirin' destanı, Yayımlanmamış yüksek lisans tezi, Ege Üniversitesi, İzmir.

Donuk, A. (1982). Çeşitli topluluklarda ve eski Türklerde aile. İstanbul Üniversitesi Edebiyat Fakültesi Tarih Dergisi, 33, 147-168.

Duralı, Ş.T. (2014). Gılgamış destanı. İstanbul: Dergâh Yayınları.

Elçin, Ş. (2005). Halk edebiyatına giriş. Ankara: Akçağ Yayınları.

Fedakâr, S. (2009). Erali ve Şirali destanı. Ankara: Türk Dil Kurumu Yayınları.

Fedakâr, S. (2016). Rüstem Han destanı. Ankara: Türk Dil Kurumu Yayınları.

Galima, M. (2001). Turan ’ın Alp kızları. Ahsen Batur (Çev.). İstanbul: Şa-To Yayınları.

Gültepe, N. (2013). Türk kadın tarihine giriş (Amazonlardan Bâcıyân-ı Rûm'a). İstanbul: Ötüken Yayınları.

Köksal, H. (2014). Battal Gazi destanı. Ankara: Akçağ Yayınları.

Malinowski, B. K. (2000) Bilimsel bir kültür teorisi. Saadet Özkal (Çev.). İstanbul: Kabalcı Yayınevi.

Oğuz, Ö. (2004). Destan tanımı ve eski Türk destanları. Milli Folklor, 62, 5-7.

Özkan, İ. (1997). Köroğlu Destanı’nda kahraman ve atının doğumu ile ilgili motiflerin tahlili. Türk Dili Dergisi, 549, 223- 233.

Saidov, M. (1960). Melike Ayyar dastanining janr hususiyetleri hakıda. Özbek Dili Ve Edebiyatı Dergisi, 1, 33-36.

Saydam, M. B. (2017). Deli Dumrul'un bilinci. İstanbul: Metis Yayınları.

Sezer, D. (2017). Dalli destanı. Ankara: Türk Dil Kurumu Yayınları. 
Solmaz, A. (2007). Ayçınar destanı. Ankara: Türk Dil Kurumu Yayınları.

Şimşek Canpolat, A. ve Öz, A., (2000). Alpamış destanı. Ankara: Atatürk Kültür Merkezi Başkanlığı Yayınlar1.

Temur, N. (2012). Manas Destanı'ndaki tipler üzerine bir inceleme. Ankara: Kurgan Edebiyat Yayınlar1.

Tekcan M. Demirci, Ü. Ö. ve Babayarov G. (2010). Polken şair Şeybani Han destant. Kocaeli: Umuttepe Yayınları.

Yetiş, K. (1994). Destan. TDV İslâm Ansiklopedisi (DIA) içinde (c. 9, ss.202). İstanbul: Diyanet Vakfı Yayınları.

Yöntem, A. C. (1930). Epope (Epopée) [Edebi nevilerle mesleklere dair malumat]. İstanbul: İstanbul Devlet Matbaasi.

Yücel, D. (2007). Melike Ayyar destanı. Ankara: Türk Dil Kurumu Yayınları.

Zarifov, H. (1957). Alpamış dastanining esasiy motivleri hakıda. Yaş Leninçi Gazetesi, 21 Şubat. 